\title{
Lectin Treatment Affects Malignant Characteristics of TPC-1 Papillary Thyroid Cancer Cells
}

\author{
Aylin Sancakli' ${ }^{\mathbb{D}}$, Engin Kaptan ${ }^{1}$ \\ IIstanbul University, Faculty of Science Department of Biology, Istanbul, Turkey
}

ORCID IDs of the authors: A.S. 0000-0001-5077-9321; E.K. 0000-0003-0866-8796

Please cite this article as: Sancakli A, Kaptan E. Lectin Treatment Affects Malignant Characteristics of TPC-1 Papillary Thyroid Cancer Cells. Eur J Biol 2019; 78(1): 51-57.

\begin{abstract}
Objective: Abnormal glycosylation is a universal aspect of cancer cells. The altered glycosylation pattern has been originated from changings in expression of glycosylation enzymes which are up-regulating in reply to some oncoproteins in the biosynthetic pathway of glycans. In this study, it was aimed to show the presence of terminal a-2,3, a-2,6 sialic acid and a-1,6/a-1,2 fucose motifs in TPC-1 papillary thyroid cancer cells. Also it was aimed to examine the changes in viability and mobility of the cells after exogenously specific lectin treatment.
\end{abstract}

Materials and Methods: In this study, the presence of terminal sugar residues in glycan chains on the cell surface was demonstrated using lectin histochemistry and lectin blotting techniques in TPC-1 cells. The changes in the cell viability and proliferation after lectin treatment were assessed using the WST-1 test. The Changes in the cell mobility after lectin treatment, however, were assessed using the wound healing test.

Results: $a-2,3, a-2,6$ sialic acid and a-1,6/a-1,2 fucose motifs were widespread in the surface of TPC-1 cells. MAL-II (Maackia amurensis Lectin II) treatment increased the cell proliferation and mobility of TPC-1 cells. Although SNA (Sambucus nigra Aglutinin) and AAL (Aleuria aurantia Lectin) treatment did not significantly affect the cell proliferation, SNA and AAL treatment supported the mobility of TPC-1 cells.

Conclusion: Lectin treatment affect cancerous properties differently depending on the cell type. Also lectin treatment can support the malignant behaviour of cancer. For this reason, it is necessary to understand the mechanisms of the lectin effect on the cancer cells.

Keywords: Papillary thyroid cancer, lectin treatment, glycosylation

\section{INTRODUCTION}

Thyroid carcinoma is one of the highly malignant disease that originates from endocrine glands. Thyroid gland consists of follicular and parafollicular (C cells) cells. There are 4 histological types of thyroid carcinoma; Papillary, follicular, medullary and anapylastic. Medullary carcinoma are originated from parafollicular $C$ cells and the others are from follicular cells (1). This classification is characterized by mutations leading to an increase in cellular proliferation and differentiation (2). Papillary thyroid carcinoma (PTC) is the most common human thyroid cancer with incidence of $80 \%$ (3). The most common genetic mutations seen in PTC are BRAF and RET at the percentage of $40-60 \%$ and RET at $20 \%$ respectively. The gene product of BRAF is known to involve in the MAPK/ERK signalling a pathway which plays an important role in various cellular processes such as cell division, differentiation and secretion. BRAF is a serine/threonine $(\mathrm{S} / \mathrm{T})$ kinase and activated by somatic point mutation occurs in $\mathrm{S} / \mathrm{T}$ domain (V600E) and the mutated form receives a mitogenic signal from RAS and transmits it to the MAP kinase pathway (4). The BRAF mutation is thought to be the key mutation for the treatment of thyroid carcinoma and for the diagnosis of aggressive PTC $(4,5)$. Another mutation seen in PTC is the telomerase reverse transcriptase (TERT) gene. It plays an important role in activity of 
telomerase enzyme during malignant transformation of cells $(6,7)$. The nucleotide of $1.295 .228 \mathrm{C}$ on the 5 th chromosome expressing this enzyme is replaced by the T nucleotide (C228T) and the 1.295.250 C nucleotide is replaced by the T nucleotide (C250T). Aberrant expression of TERT causes cell proliferation without changing the length of telomerase in human $(8,9)$.

Glycosylation is a posttranslational or cotranslational modification required in many proteins to perform many cellular functions. Glycan chains linked to proteins plays role in physiological processes such as intracellular protein trafficcing, signal transduction, cell-cell interaction, cell-extracellular matrix (ECM) interaction, differentiation (10). Also it has an important role in the pathophysiological processes (11). Glycoconjugates are glycosylated biomolecule groups and they have been shown to take part in the development and progression of cancer (12). Additionally, cancer-associated glycoconjugates in blood serum and tissues are used as a marker for determining the progression of the disease (13). Altered or aberrant glycosylation is a common pathological processes in the various type of cancers. This processes is performed by many glycosylation enzymes, which participate in the biosynthetic pathways of glycans, up-regulated in reply to some oncogenic proteins (14). Changes in the expression of these kind of enzymes induce differences in the synthesis of the glycan chains found in membrane glycolipids and glycoproteins (15). This phenomena are also observed in the processes such as embryogenesis, regeneration and inflammation (16).

In the present study, we aimed to examine the existence of $a-2,3, a-2,6$ sialic acid and a-1,6/ a-1,2 fucose motifs, which are common terminal sugars of several cancers. In addition, we aimed to show the possible effects of the lectins having binding ability to terminally located $a-2,3$ sialic acid, $a-2,6$ sialic acid $a-1,6 / a-1,2$ fucose motifs on cell viability/proliferation and mobility.

\section{MATERIALS AND METHODS}

\section{Cell Culture}

TPC- 1 cells were cultured at $37^{\circ} \mathrm{C}$ with $5 \% \mathrm{CO}_{2}$ at 1 atmospheric pressure in Dulbecco's modified Eagle medium (DMEM) containing $10 \%$ fetal bovine serum (FBS) and antibiotics (100 $\mathrm{U} / \mathrm{mL}$ penicillin ve $100 \mu \mathrm{g} / \mathrm{mL}$ streptomycin). Firstly, cells with sufficient density were washed with sterile PBS (Phosphate Buffered Saline) without calcium-magnesium. The cells were removed from petri dish with $2.5 \%$ sterile Trypsin-EDTA (Ethylene Diamine Tetraacetic Acid). For freezing of the cells, the freezing medium prepared with $90 \%$ FBS and $10 \%$ was used and transferred to $-152^{\circ} \mathrm{C}$ for periodic storage.

\section{Cell Surface Lectin-Fluorescent Staining}

The aim of this method is to determine $a-2,3$ and $a-2,6$ sialic acid and $a-1,6 / a-1,2$ fucose motifs on TPC- 1 cell surface. For this purpose, 25.000 cells were transferred to each well of 24well plate with $12 \mathrm{~mm}$ diameter sterile coverslip. The cells with sufficient density were rinsed with HEPES $(\mathrm{pH} 7.5)$ and then the cells fixed in $4 \%$ paraformaldehyde ( $\mathrm{pH}$ 7.2) for $10 \mathrm{~min}$ in a $37^{\circ} \mathrm{C}$ incubator. After washing, the cells incubated in HEPES containing $50 \mathrm{mM}$ ammonium chloride $\left(\mathrm{NH}_{4} \mathrm{Cl}\right)$ for $5 \mathrm{~min}$ and blocked with BSA for $10 \mathrm{~min}$. The sugar residues on the cell surfaces were labelled with $2.5 \mu \mathrm{g} / \mathrm{ml}$ biotinylated MAL-II, SNA and AAL (Vector Lab. UK) lectins for 1 hour at room temperature and then cells were incubated with Cy3-conjugated Streptavidin (ThermoFisher-Scientific, USA) and ProLong Gold antifade reagent (ThermoFisher-Scientific, USA) with DAPI which was used to distinguish the nuclei of the cells. To check out lectin binding specificity, two negative control were designed namely, untreated and inhibitory sugars (MAL-II/3'sialillactose, SNA/6'sialillactose, AAL/L-fucose) groups. Lectin binding activity in the surface of the cells were observed with an epiilluminated fluorescence microscope (Nikon, Eclipse-Ti-U) and photographed with a camera (Nikon, DSRi1).

\section{Lectin Blotting}

Membrane Protein Extraction Kit (ThermoFisher-Scientific, USA) was used for the isolation of membrane proteins. The cells were harvested from the flask with the cell scraper and centrifuged at $3000 \mathrm{~g}$. Membrane proteins were obtained following the instructions of the product manual. The amount of the proteins was determined using the Bradford protein determination method and $30 \mu \mathrm{g} / \mathrm{ml}$ membrane protein samples were loaded in each well of $4-12 \%$ Bis-tris gradient acrylamide gel. The electrophoretically separated proteins in the gel were transferred onto nitrocellulose membrane using Novex iblot gel transfer system (ThermoFisher-Scientific, USA). After transferring step, the membrane was incubated in $1 \mu \mathrm{g} / \mathrm{ml}$ biotinylated MAL-II, SNA and AAL lectins at room temperature for 1 hour. The biotinylated lectins were labelled by incubating cells with $2 \mu \mathrm{g} / \mathrm{ml}$ HRP-conjugated Streptavidin in PBST (Phosphate buffered Saline-Tween 20) at room temperature for 1 hour. After that, cells were washed with PBST and the lectin specific sugar motifs on the cell surface were visualized by the gel imaging system (KODAK Gel Logic System 1500) using the Novex ECL HRP Chemiluminescent Substrate Reagent Kit.

\section{Cell Viability and Proliferation Assay}

In order to investigate the effect of MAL-II, SNA and AAL unconjugated lectins on the viability of TPC-1 cell lines, WST-1 test was performed with 50.000 cells per well of 96 well plates. The cells treated with the lectins in doses ranging from 0,001 to $1 \mu \mathrm{M}$ for 24 and 48 hours and, $10 \mu \mathrm{l}$ WST- 1 reagent was treated to these cells and incubated in a $37^{\circ} \mathrm{C}$ incubator for 30 minutes. The plate was stirred for $60 \mathrm{~min}$ in a shaker and the absorbance at $440 \mathrm{~nm}$ were taken using $\mu$ Quant plate reader (BioTek, Vinooski, VT). Cell viability and proliferation data obtained from three independent experiments and performed in triplicate wells.

\section{Wound Healing Assay}

According to the data obtained from the cell viability test, two different doses which do not cause any increase in the number of cells were selected for each lectin and used in the wound healing test in order to investigate the effects of the cells on the cell mobility. TPC-1 cells were seeded on 6-well plates in certain numbers. When the cells reached a density of $70-80 \%$, 
a wound model was created by carefully drawing horizontal and vertical lines with $200 \mu \mathrm{l}$ pipette tip to the bottom of the wells. Unconjugated lectins were treated to the wound model for 24 and 48hours and wound width was measured with NISElements D 3.1 software after at 0, 24 and 48 hours. Using the data obtained, the percentage of wound width was calculated in terms of the formula; Wound width $\%=$ (Wound width at 24 or $48 \mathrm{~h}$ )/(Wound width at $0 \mathrm{~h}) \times 100$.

\section{Statistical Analysis}

Statistical analysis were made using SPSS software. The paired comparisons of the parameters with the control groups were performed using the t-test. ANOVA analysis and Tukey postoc test were used for multiple comparisons. Microsoft Excell program was used to draw graphics.

\section{RESULTS}

\section{Terminal Sugar Residues of TPC-1 Cell Surface}

In order to show $a-2,3, a-2,6$, terminal sialic acid and a-1,6/a-1,2 terminal fucose motifs on cell surfaces, MAL-II, SNA and AAL lectins specific for these motifs were used respectively. Fluorescent intensities were obtained from lectin staining study with biotinylated lectins and Cy3-streptavidin. The presence of $a-2,3$ and $a-2,6$ sialic acid and $a-1,6 / a-1,2$ fucose motifs were evident on the cell surface of TPC-1 cells. However, $a-2,3$ sialic acid and $a-1,6$ fucose motifs were significantly higher than $a-2,6$ sialic acid motifs ( $p \leq 0.001$ ) (Figures $1 A$ and $1 B)$. The data obtained from lectin blotting studies showed that there were terminal $a-2,3$ and $a-2,6$ sialic acid and $a-1,6 / a-1,2$ fucose sugars in the membrane proteins of TPC-1 cell. The membrane glycoproteins glycosylated with terminally $a-2,3$ sialic acid in TPC- 1 cells were ranging from 40 to $80 \mathrm{kDa}$. Its terminally $a-2,6$ sialillated membrane glycoproteins were ranging from 20 to $110 \mathrm{kDa}$. Its terminally a-1,6/a-1,2 fucosylated membrane glycoproteins, however, were ranging from 30-160 kDa (Figure 1C). Although $a-2,6$ sialilation was weaker than the others when considering SNA fluorescent density in TPC-1, $a-2,6$ sialilated membrane glycoproteins more diverse than the other sugar glycosylation when considering lectin blotted membranes (Figures 1A-C).

\section{Effects of Lectins on TPC-1 Cell Viability}

When TPC-1 cells treated with MAL-II lectin for 24 hours, the cell viability of TPC-1 cells increased in a dose dependent manner at doses among 0.001 and $0.05 \mu \mathrm{M}$. However, the cell viability decreased in dose dependent manner at doses among $0.05-1 \mu \mathrm{M}$. On the other hand, no significant changes were observed in the cell viability of SNA and AAL lectins $24 \mathrm{~h}$ treated groups in TPC-1 cells at the dose range of $0.001-1 \mu \mathrm{M}$ (Figure $2 \mathrm{~A}$ ). The results of $48 \mathrm{~h}$ SNA and AAL lectin treatment in TPC -1 cells at the dose range of $0.001-1 \mu \mathrm{M}$ were not similar to the findings those of $24 \mathrm{~h}$ SNA and AAL lectin treatment (Figure $2 B$ ). Some significant fluctuations in the viability of TPC- 1 cells were observed in $48 \mathrm{~h}$ SNA lectin treatment. A statistically insignificant $38 \%$ increase was observed in the $0.1 \mu \mathrm{M}$ dose compared to the control. However, the viability of SNA treated
TPC-1 cells decreased in dose dependent manner. AAL lectin treatment to TPC- 1 cells at a dose range of $0.001-1 \mu \mathrm{M}$ for 24 hours increased the cell viability in dose dependent manner up to $25 \%$. It was found that the increase in the viability of these cells was statistically significant at $0.5,0.1,0.25(p \leq 0.05)$ and $0.5 \mu \mathrm{M}(\mathrm{p} \leq 0.01)$ (Figure $2 \mathrm{~B})$.

\section{Effects of Lectins TPC-1 Cell Mobility}

Increased cell mobility was observed in both $0.001 \mu \mathrm{M}$ and $0.005 \mu \mathrm{M}$ doses in $24 \mathrm{~h}$ and $48 \mathrm{~h}$ MAL-II lectin treated TPC-1 cells. A significant enhancement in cell mobility was monitored, especially at the concentration of $0.001 \mu \mathrm{M}$. The wound closure was quicker than untreated control cells $(p \leq 0.001)$. There was also a statistically significant increase at MAL-II concentration of $0.001 \mu \mathrm{M}$ in $48 \mathrm{~h}$ treatment $(\mathrm{p} \leq 0.05)$. Insignificant increase in cell mobility were observed in $48 \mathrm{~h}$ treatment of MAL-II at $0.005 \mu \mathrm{M}$ concentration when compared to control (Figure 3). $24 \mathrm{~h}$ and $48 \mathrm{~h}$ SNA lectin treatment for the doses $0.005 \mu \mathrm{M}$ and $0.01 \mu \mathrm{M}$ augmented the cell mobility of TPC-1 cells in a dosedependent manner. However, this increase is only statistically significant at 48 hours at a concentration of $0.005 \mu \mathrm{M}(\mathrm{p} \leq 0.05)$ (Figure 4). A statistically significant increased cell mobility was observed in both concentrations of $0.001 \mu \mathrm{M}$ and $0.005 \mu \mathrm{M} \mathrm{AAL}$ for $24 \mathrm{~h}$ treatment (Figure 5). The closure was quicker in both doses of $A A L$ than the untreated control group $(p \leq 0.05)$. Overall results of MAL-II treatment suppressed wound closure of TPC-1 cells at all doses tested when compared to untreated control. The wound width of $24 \mathrm{~h}$ and $48 \mathrm{~h}$ lectin treated cells were narrower than that of untreated control with various statistical significances.

\section{DISCUSSION}

Recent studies have shown that most of the lectins have anticarcinogenic feature. This fact generally occurs when lectins link to glycan chains in the tumor cell membrane to produce various effects. Mechanical details are not yet known, but there are so many pieces of evidence that lectins may inhibit or activate protein function by binding to glycan chains of glycoproteins in different cellular compartments (17). Thus, the lectin interaction in different cellular compartments can give rise to some toxic effects such as decrease in protein synthesis or cell death stimulation.

Our results pointed out that MAL-II treatment to TPC-1 cells, which are papillary thyroid cancer cell line, increased the cell proliferation at the dose range of $0.001-1 \mu \mathrm{M}$. Similar to our findings PNA, which is peanut lectin and recognizes Gal $\beta-1,3$ GalNAc (TF-antigen) motifs, had also been shown to have a proliferative effect on HT29 colon cancer cells (18, 19). MAL-II treatment at the concentration range of $0.8-8 \mu \mathrm{M}$ demonstrated to induce apoptosis in lung cancer cell lines (20). Chen et al., (2009) showed that sialic acid specific PCL lectin purified from Phaseolus coccineus plant was highly toxic on L929 fibrosarcoma cells. As a result of this toxic effect, apoptotic death in the cells was more dominant but they also observed that it stimulated necrotic death (21). 
(A)
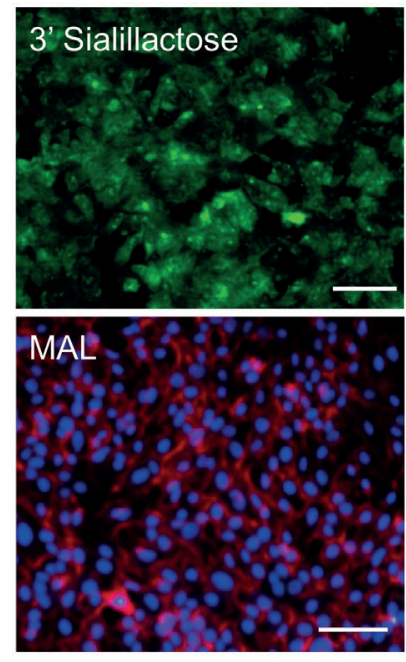

(B)

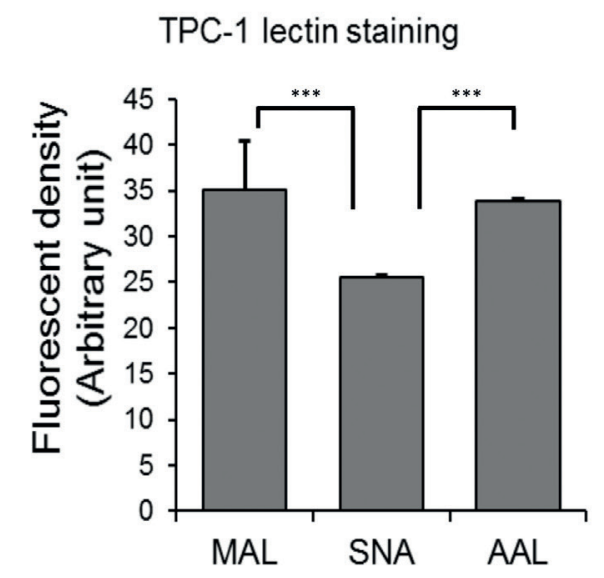

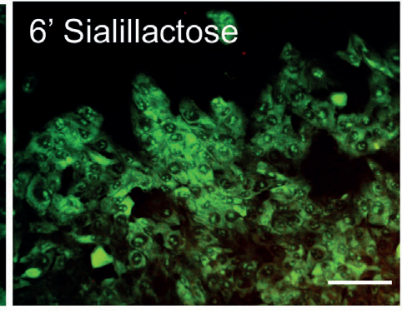
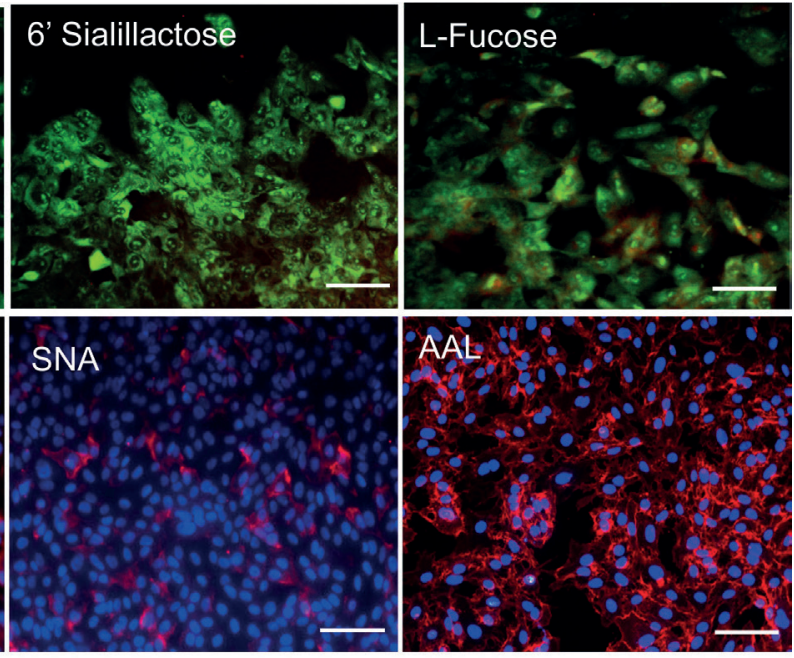

(C)

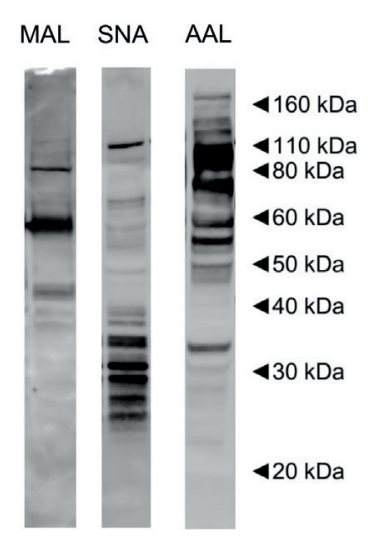

Figure 1. Alpha-2,3/2,6 sialic acid and a-1,6/a-1,2 fucose motifs in the cell surface of human papillay thyroid carcinoma cell lines TPC-1. The fluorescent micrographs of cell surface lectin binding assays and their inhibitory sugar controls (A) and the surface fluorescence intensity of the cells after biotinylated MAL-II, SNA and AAL lectin-staining (B) and the membrane glycoprotein profile having MAL-II, SNA and AAL affinities in the membrane protein fraction of TPC-1 cells blotted on nitrocelluse membrane. The detected bands display the specific glycosylation status ( $a-2,3, a-2,6$ sialic acid and a-1,6/a-1,2 fucose residues) of membrane glycoproteins of TPC-1 cells (C). Fluorescence intensity data are represented as the mean \pm SD. Asterisc $\left(^{* * *}\right)$ shows significance $(p \leq 0.001)$ compared to one another. The scale bar is $50 \mu \mathrm{m}$.

Similarly, mannose binding lectin acquired from Sophora flavescens had a toxic effect on HeLa cells and it caused apoptotic and necrotic death (22). ACA lectin acquire from Amaranthus caudatus plant can bind to TF-antigen motifs same as PNA $(23,24)$ and it was found to significantly increase the proliferation of HT29 colon cancer cells (25). Based on our results, consumption of plant nutrients or extracts containing a-2,3 sialic acid binding lectins seems unfavorable for the papillary thyroid cancer patients. Because lectins are protein or glycoprotein nature and they are protected from gastrointestinal proteolysis and they can enter the circulatory system. The researchers reported that bioactive PNA lectin reached an average serum concentration of $50 \mathrm{nM}$ after 200 gr of peanut consumption (26).
The researchers stated that decrease in invasive character of melanoma cells after MAL-II treatment was originated from increased $a-2,3$ sialic acid motifs of podoplanin which is extracellular domain of the mucin receptor. Podoplanin is also responsible for invasiveness of melanoma cells (27). In another study, it was found that only $\beta 1$ unit of a5 $\beta 1$ integrin in melanoma cells was decorated with $a-2,3$ sialic acid residues and MAL-II lectin treatment gave rise to a significant reduce in the mobility of cells. MAL-II lectin treatment revealed better results than SNA lectin treatment, which have affinity to $a-2,6$ sialic acid, in the matter of suppressing melanoma cell mobility (28). In addition, MAL-II and SNA lectin treatment to $8505 \mathrm{C}$ anaplastic and $\mathrm{K} 1$ papillary thyroid cancer cells has been shown to be effective in suppressing 
(A)

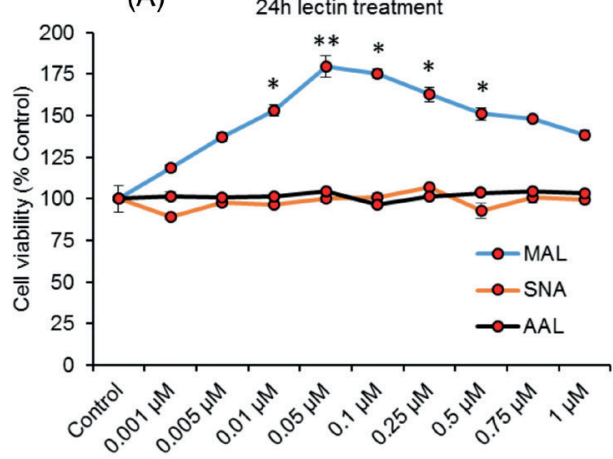

(B)

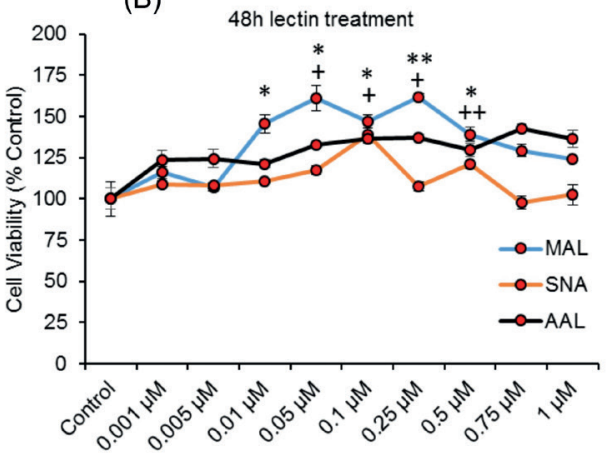

Figure 2. MAL-II, SNA and AAL treatments affect on the survival of human papillary thyroid carcinoma cell lines TPC-1. Changes in the cell viability in $24 \mathrm{~h}(\mathrm{~A})$ and $48 \mathrm{~h}$ lectin treatment $(\mathrm{B})$ at doses among $0.0001-1 \mu \mathrm{M}$. The data are represented as the mean \pm SD. Asteriscs $(* * *)$ show significance $(p \leq 0.05 / p \leq 0.01)$ between treated and untreated groups.
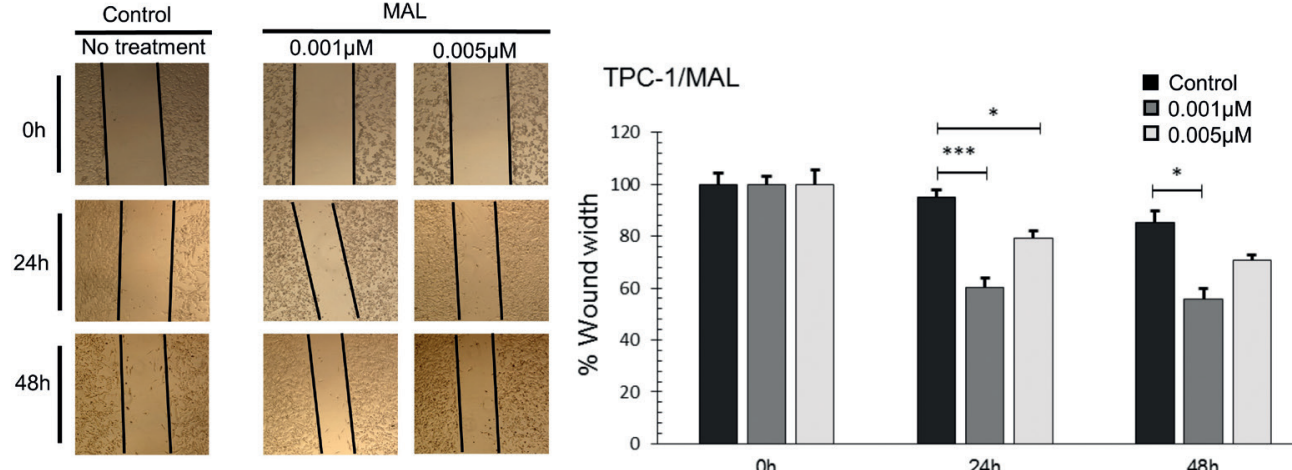

Figure 3. MAL-II treatment affects on the mobility of human papillary thyroid carcinoma cell line TPC-1 and, 0.001 and $0.005 \mu \mathrm{M}$ MAL-II treatments augmented the cell mobility of TPC- 1 cell. Wound width percentages are represented as the mean \pm SD. Asteriscs $\left({ }^{*} / * * *\right)$ show significance $(p \leq 0.05 / p \leq 0.001)$ between treated and untreated groups.
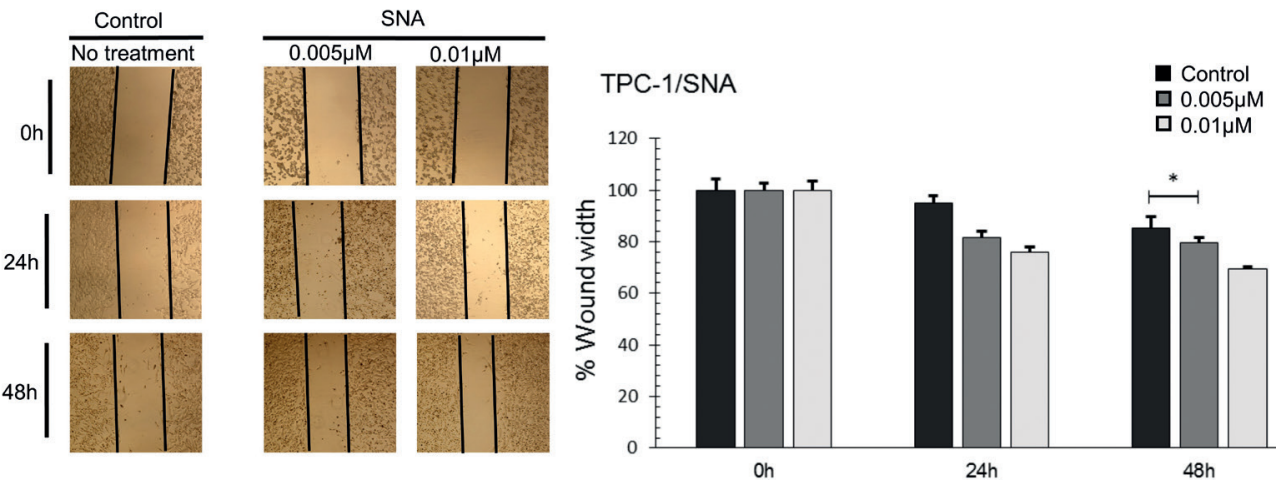

Figure 4. SNA treatment affects on the mobility of human papillary thyroid carcinoma cell line TPC-1 and, 0.005 and $0.01 \mu \mathrm{M}$ SNA treatments enhanced the cell mobility of TPC- 1 cell. Wound width percentages are represented as the mean \pm SD. Asterisc $(*)$ shows significance $(p \leq 0.05)$ between treated and untreated groups.

cell migration. However, it has been demonstrated that AAL treatment increases the mobility of $8505 \mathrm{C}$ cells. It has been also shown that MAL-II and SNA treatment to FTC-133 follicular thyroid cancer cells increases cell mobility (29). Our findings have been pointed out that MAL-II, SNA and AAL lectin treatment significantly increase cell mobility on TPC-
1 papillary cancer cells. Although limited number of study have been focused on the effects of lectins related to cell mobility, overall findings have indicated that lectin treatment can affect cell mobility differently depending on the cancer types and even depending on the cancer cell types. It can be suggested that lectin effect comes out in cancer cells 

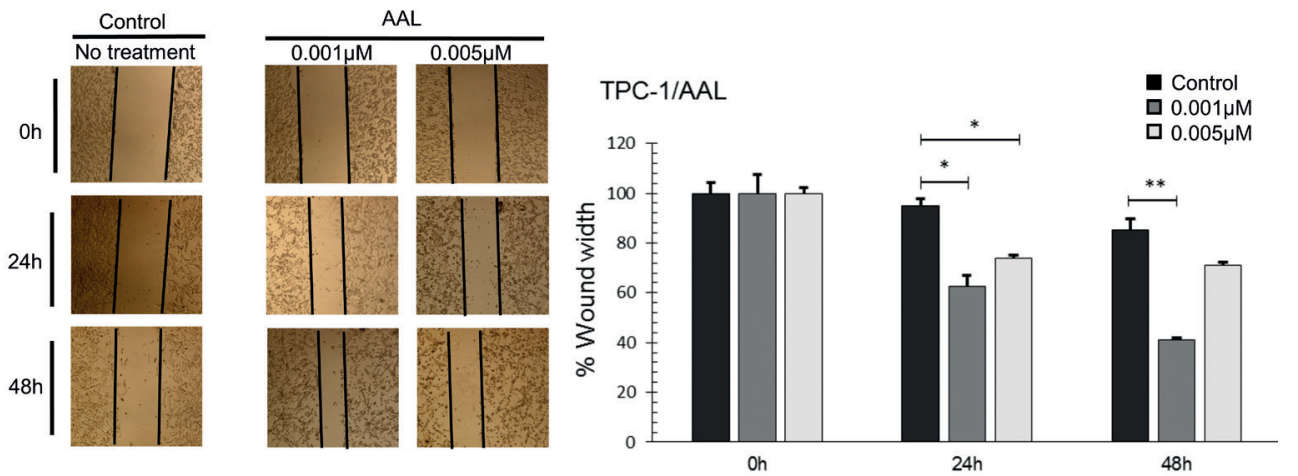

Figure 5. AAL treatment affects on the mobility of human papillary thyroid carcinoma cell line TPC-1 and, 0.001 and $0.005 \mu \mathrm{M}$ AAL treatments increased the cell mobility of TPC- 1 cell. Wound width percentages are represented as the mean \pm SD. Asteriscs $(* / * *)$ show significance $(p \leq 0.05 / p \leq 0.01)$ between treated and untreated groups.

with respect to which cell surface proteins will decorate themselves with the altered sugar chains. Therefore, further studies with a mechanistic perspective should consider glycosidic modifications of membrane proteins.

\section{CONCLUSION}

In this study, we examined the effects of lectins targeting to cell surface glycosidic phenotype of papillary cancer cells. Particularly, it was found that the MAL-II treatment supported the aggressive features of the cancer cells. Despite the studies demonstrating the anticancer properties of some lectins, our study have pointed out that lectins can support the poor prognosis of cancer. Also, the present study underscores the need for investigation about the effects of lectins on cancer cells in further details. Because, the nutritional plants contain lectins and they pass through the digestive system without being broken down by proteolytic enzymes and pass into the bloodstream. Therefore, this situation can be considerable for cancer patients. That is why studies on the identification of lectins found in nutritional plants and how they affect cancer cells are of great importance.

Peer-review: Externally peer-reviewed.

Author Contributions: Conception/Design of study: E.K.; Data Acquisition: A.S., E.K.; Data Analysis/Interpretation: E.K., A.S.; Final Approval and Accountability: E.K., A.S.; Drafting Manuscript: E.K., A.S.; Critical Revision of Manuscript: E.K., A.S.; Technical or Material Support: E.K., A.S.; Supervision: E.K.

Conflict of Interest: The authors declare that they have no conflicts of interest.

Financial Disclosure: There are no funders to report for this submission

Acknowledgements: This study was supported by the grant from Istanbul University, Unit of Scientific Research Projects (IU. BAP, project no: 46177)

\section{REFERENCES}

1. Xing M. Molecular pathogenesis and mechanisms of thyroid cancer. Nat Rev Cancer 2013; 13(3):184-99.

2. Catalano MG, Poli R, Pugliese M, Fortunati N, Boccuzzi G. Emerging molecular therapies of advanced thyroid cancer. Mol Aspects Med 2010; 31(2): 215-26.

3. KondoT, Ezzat S, Asa SL. Pathogenetic mechanisms in thyroid follicular-cell neoplasia. Nat Rev Cancer 2006; 6(4): 292-306.

4. Xing M. Prognostic utility of BRAF mutation in papillary thyroid cancer. Mol Cell Endocrinol 2010; 321(1): 86-93.

5. Nucera C, Lawler J, Hodin R, Parangi S. The BRAFV600E mutation: what is it really orchestrating in thyroid cancer? Oncotarget 2010; 1(8): 751-6.

6. Janknecht R. On the road to immortality: hTERT upregulation in cancer cells. FEBS Lett 2004; 564(1-2): 9-13.

7. Bodnar AG, Ouellette M, Frolkis M, Holt SE, Chiu CP, Morin GB, Harley CB, Shay JW, Lichtsteiner S, Wright WE, Extension of lifespan by introduction of telomerase into normal human cells. Science 1998; 279(5349): 349-52.

8. Hrdličková R, Nehyba J, Bose HR. Alternatively spliced telomerase reverse transcriptase variants lacking telomerase activity stimulate cell proliferation. Mol Cell Biol 2012; 32(21): 4283-96.

9. Sarin KY, Cheung P, Gilison D, Lee E, Tennen RI, Wang E, Artandi $\mathrm{MK}$, Oro $\mathrm{AE}$, Artandi SE. Conditional telomerase induction causes proliferation of hair follicle stem cells. Nature 2005; 436(7053): 1048-52

10. Reinders J, Sickmann A. Modificomics: posttranslational modifications beyond protein phosphorylation and glycosylation. Biomol Eng 2007; 24(2): 169-77.

11. Freeze HH, Chong JX, Bamshad MJ, Ng BG. Solving glycosylation disorders: fundamental approaches reveal complicated pathways. Am J Hum Genet 2014; 94(2): 161-75.

12. Schultz MJ, Swindall AF, Bellis SL. Regulation of the metastatic cell phenotype by sialylated glycans. Cancer Metastasis Rev 2012; 31(3-4): 501-18.

13. Reis CA, Osorio H, Silva L, Gomes C, David L. Alterations in glycosylation as biomarkers for cancer detection. J Clin Pathol 2010; 63(4): 322-9.

14. A. Varki, R. Kannagi, and B. P. Toole, "Glycosylation changes in cancer" in Essentials of Glycobiology, A. Varki, R. D. Cummings, J. D. Esko et al., Eds., 2009. 
15. Meany DL, Chan DW. Aberrant glycosylation associated with enzymes as cancer biomarkers. Clin Proteom 2011; 8(1): 7.

16. Martin LT, Marth JD, Varki A, Varki NM. Genetically altered mice with different sialyltransferase deficiencies show tissue-specific alterations in sialylation and sialic acid 9-O-acetylation. J Biol Chem 2002; 277(36): 32930-8.

17. De Mejía, E.G. and Prisecaru, V.I., (2005). Lectins as bioactive plant proteins: a potential in cancer treatment. Crit Rev Food Sci Nutr 45(6): 425-45.

18. Ryder SD, Smith JA, Rhodes JM. Peanut lectin: a mitogen for normal human colonic epithelium and human HT29 colorectal cancer cells. J Natl Med Assoc 1992; 84(18): 1410-6.

19. Singh R, Subramanian S, Rhodes JM, Campbell BJ. Peanut lectin stimulates proliferation of colon cancer cells by interaction with glycosylated CD44v6 isoforms and consequential activation of c-Met and MAPK: functional implications for disease-associated glycosylation changes. Glycobiology 2006; 16(7): 594-601.

20. Mehta S, Chhetra R, Srinivasan R, Sharma SC, Behera D. Ghosh S. Potential importance of Maackia amurensis agglutinin in nonsmall cell lung cancer. Biol Chem 2013; 394(7): 889-900.

21. Chen J, Liu B, Ji N, Zhou J, Bian HJ, Li CY, Chen F, Bao JK, A novel sialic acid-specific lectin from Phaseolus coccineus seeds with potent antineoplastic and antifungal activities. Phytomedicine 2009; 16(4): 352-60.

22. Liu Z, Liu B, Zhang ZT, Zhou TT, Bian HJ, Min MW, Liu YH, Chen J, Bao JK. A mannose-binding lectin from Sophora flavescens induces apoptosis in HeLa cells. Phytomedicine 2008; 15(10): 867-75.
23. Hagiwara K, Collet-Cassart D, Kunihiko K, Vaerman JP. Jacalin: isolation, characterization, and influence of various factors on its interaction with human $\lg A 1$, as assessed by precipitation and latex agglutination. Mol Immunol 1988; 25(1): 69-83.

24. Ahmed H, Chatterjee BP. Further characterization and immunochemical studies on the carbohydrate specificity of jackfruit (Artocarpus integrifolia) lectin. J Biol Chem 1989; 264(16): 9365-72.

25. Yu LG, Milton JD, Fernig DG, Rhodes JM. Opposite effects on human colon cancer cell proliferation of two dietary ThomsenFriedenreich antigen-binding lectins. J Cell Physiol 2001; 186(2): 282-7.

26. Wang Q, Yu LG, Campbell BJ, Milton JD, Rhodes JM. Identification of intact peanut lectin in peripheral venous blood. Lancet 1998; 352(9143): 1831-2.

27. Ochoa-Alvarez JA, Krishnan H, Pastorino JG, Nevel E, Kephart D, Lee JJ, Retzbach EP, Shen Y, Fatahzadeh M, Baredes S, Kalyoussef E. Antibody and lectin target podoplanin to inhibit oral squamous carcinoma cell migration and viability by distinct mechanisms. Oncotarget 2015; 6(11): 9045-60.

28. Kolasińska E, Przybyło M, Janik M, Lityńska A. Towards understanding the role of sialylation in melanoma progression. Acta Biochim Pol 2016; 63(3): 533-41.

29. Kaptan E, Sancar-Bas S, Sancakli A, Bektas S, Bolkent S. The effect of plant lectins on the survival and malignant behaviors of thyroid cancer cells. J Cell Biochem 2018; 119(7): 6274-87. 